Volume 39 | Issue 2 | December 2015

ISSN 1030-0112

\title{
Atustirallasjan Journal of
}

SPECJa!

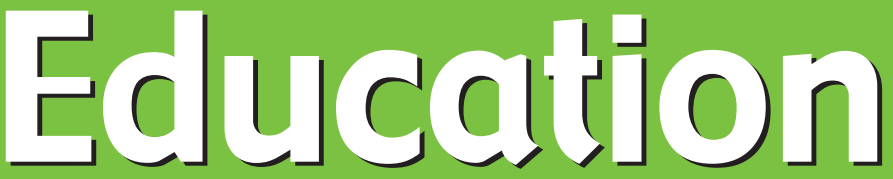

Journal of the Australian Association of Special Education

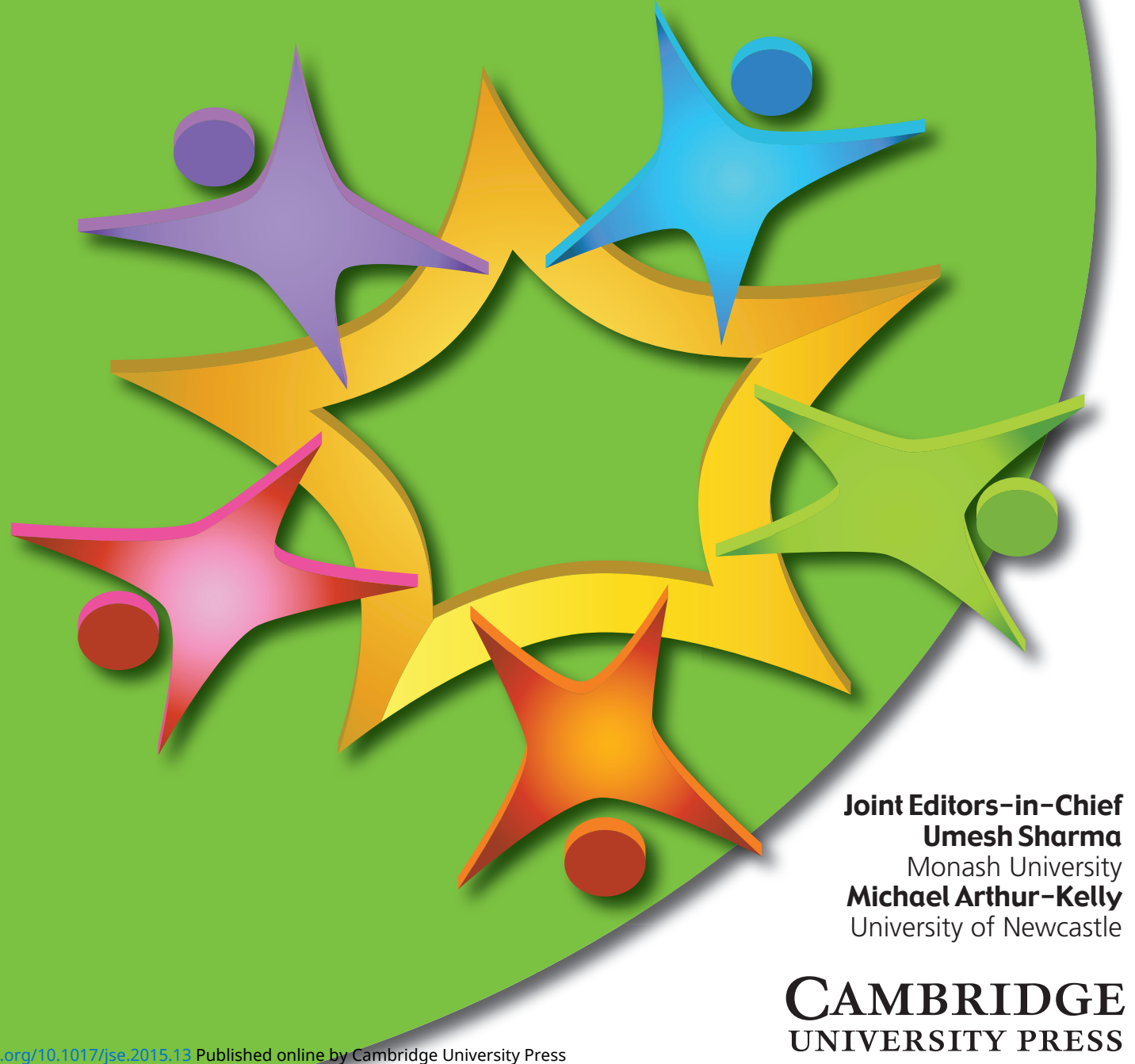




\section{Australasian Journal of Special Education}

The Australian Association of Special Education (AASE) aims to enhance access for students with special education needs to quality educational programs, promote professional standards of a high order and to support research that informs the delivery of special education in the Australian context.

To further these aims, The Australasian Journal of Special Education publishes articles for a readership professionally engaged or interested in the education of students with special needs or the education of those who will work with these students.
The Editor seeks articles in line with the theme of the journal — the delivery of educational programs to persons with special education needs: case studies, position papers, research reports, review papers and descriptions of research-based programs or classroom practices. Articles may be original qualitative or quantitative research papers, literature reviews, or conceptual articles relevant to any aspect of special education practice and policy.

\section{Editor Contact}

For any queries contact the Assistant Editor at Genevieve.Farrell@newcastle.edu.au

\section{Peer Review Policy}

All articles in this journal have undergone rigorous peer review, based on initial editor screening and anonymous refereeing by at least two expert referees.

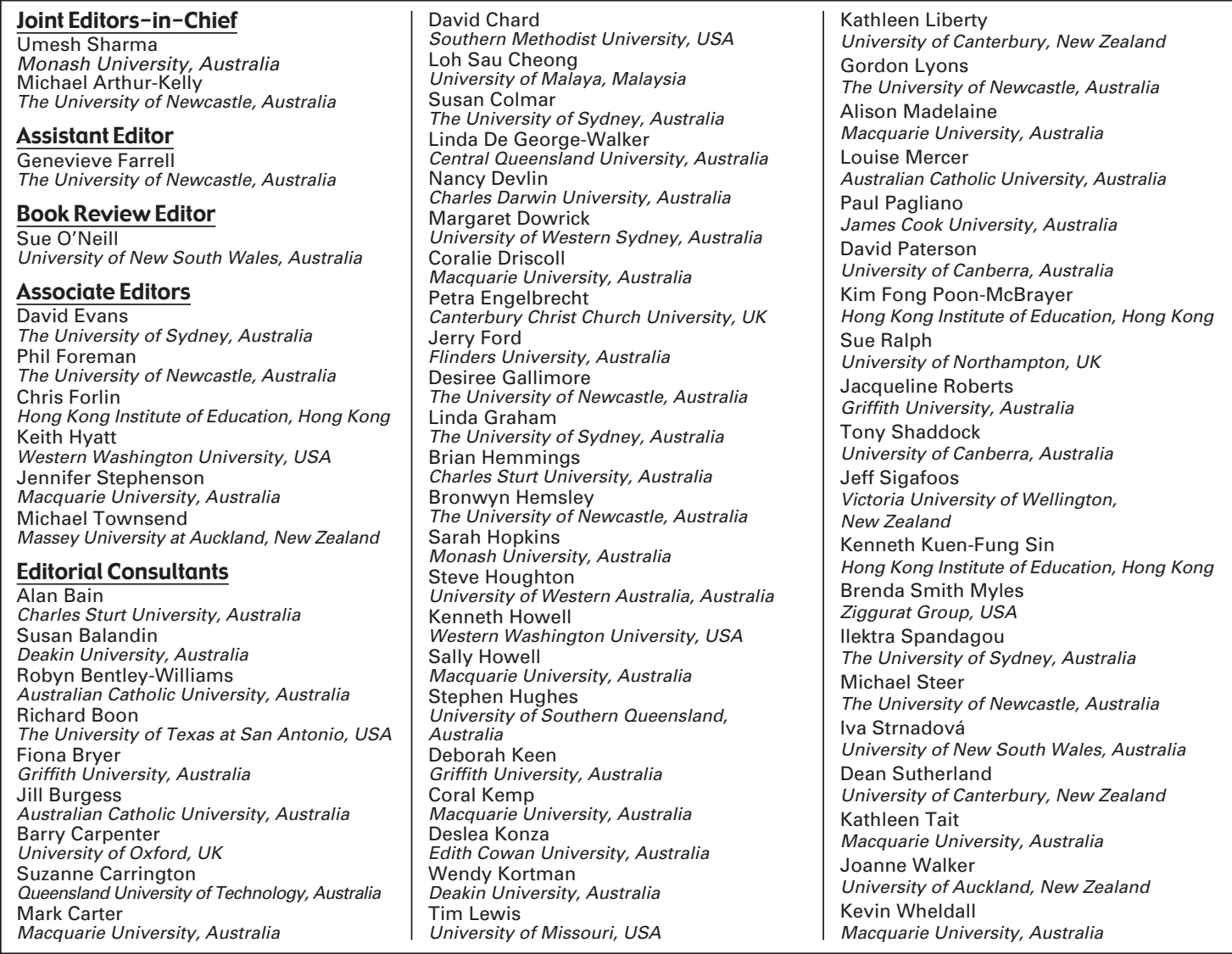

\section{Australian Association of Special Education Incorporated}

President: Colleen Crawford (TAS)

Vice Presidents: Jennifer Stephenson (NSW) and Ian Copland (ACT)

Secretary: Carmel Blake (NT)

Treasurer: Virg Hughes (NT)

Immediate Past President:

Lynne James (TAS)

Executive Officer: Libby Burns

(SA)

National Office

PO Box 211

GLEN IRIS VIC 3146

Membership Office

PO Box 1221

BURWOOD NSW 1805

E-mail: office@aase.edu.au

\section{STATE CHAPTERS}

C/O PO Box 1221

BURWOOD NSW 1805

E-mail: office@aase.edu.au
Subscription Rates 2015

This journal is published biannually.

The institutional rates (excluding VAT) are:

Print and online

Australia

N America

298 AUD

325 USD

210 GBP

277 AUD

304 USD

197 GBP

EU subscribers (outside the UK) who are not registered for VAT should add VAT at their country's rate. VAT registered subscribers should provide their VAT registration number. Prices include delivery by air when appropriate. Japanese prices for institutions are available from Kinokuniya Company Ltd, P.O. Box 55, Chitose, Tokyo 156, Japan. Orders and subscription enquiries should be addressed to: Cambridge University Press, Journals Fulfillment Department, UPH, Shaftesbury Road, Cambridge CB2 8BS, UK.

Orders from N America should be addressed to:

Cambridge University Press, Journals Fulfillment Department, 100 Brook Hill Drive, West Nyack, NY 10994-2133, USA

Journal subscription is covered by membership to the Australian Association of Special Education. For all enquiries, please contact the association:

PO Box 1221, Burwood, NSW 1805, Australia

Australasian Journal of Special Education and all other Cambridge Journals can be found at http://journals.cambridge.org/ 


\section{Austiralasian Jounal of \\ Special Educalion}

\section{Volume 39 | Issue 2 | December 2015}

\section{Contents}

\section{Articles}

Teacher Perceptions of Factors for Successful Inclusive Early Childhood Education in Hong Kong

Frances Lai Mui Lee, Alexander Seeshing Yeung, Katrina Barker, Danielle Tracey and Jesmond C. M. Fan

Parent Perspectives on Sources of Information About Autism Spectrum Disorder Interventions in Australia

Sarah Carlon, Jennifer Stephenson and Mark Carter

Asperger's and Girls: What Teachers Need to Know

Belinda Jarman and Christopher Rayner

Insights Into the Support Services for Students

Copyright in all articles rests with authors. A limited set of permanent copyright permission licences has been granted by authors to the publisher to allow publication in this journal. Rights in the reproduction and distribution of the published articles as visual facsimiles of this published edition by either mechanical or digital means is controlled by the publisher and any distributions by CAL for copying of an author's work therefore are due to the publisher and AASE. All other rights in the words contained in this edition are controlled by the authors. Authors are therefore free to adapt and/or republish the words making up their own articles either online or in print.

Published by Cambridge University Press on behalf of the Australian Association of Special Education Inc.

Cambridge University Press,

University Printing House

Shaftesbury Road

Cambridge CB2 8BS

United Kingdom

journals.cambridge.org

With Vision Impairment

Poulomee Datta and Carolyn Palmer 